\title{
The Impact of Brand Identification, Brand Equity, Brand Reputation on Brand Loyalty: Mediating Role of Brand Affect in Pakistan
}

\author{
Tayyaba Mahmood ${ }^{1}$, Shumaila Qaseem ${ }^{1}$, Qazi Muhammad Ali ${ }^{1}$, Hafiz Fawad Ali ${ }^{2}$, Dr Asad Afzal Humayon ${ }^{3} \&$ \\ Amna Gohar ${ }^{4}$ \\ ${ }^{1}$ Superior University, Lahore, Pakistan \\ ${ }^{2}$ Institute of Business Administration, University of the Punjab, Lahore, Pakistan \\ ${ }^{3}$ COMSAT, Vehari Campus, Pakistan \\ ${ }^{4}$ Lahore Garrison University, Pakistan \\ Correspondence: Shumaila Qaseem, Superior University, Lahore, Pakistan. E-mail: shumailaqaseem78@gmail.com
}

Received: November 12, 2018

Accepted: December 10, $2018 \quad$ Online Published: December 12, 2018

doi:10.5430/bmr.v7n4p46

URL: https://doi.org/10.5430/bmr.v7n4p46

\begin{abstract}
Brand loyalty has been an important factor for quite a while in marketing structure of the organizations. Organizations tend to achieve brand loyalty through employing different strategies and by engaging customers to produce a sense of belongingness among them regarding the brand. One of the major sector that has shown a great trend and growth in recent era is the apparel industry of Pakistan. However, little studies have tried to conceptualize and check the influence of brand related concepts on the brand loyalty in Pakistan. Current study has tried to check the influence of Brand Reputation, Brand Identification, Brand Equity and Brand Effect on Brand Loyalty. An important contribution of the study was to consider the brand affect as the mediating variable among the Brand Reputation, Brand Identification, Brand Equity and Brand Loyalty. 180 questionnaires were distributed among the students of the universities and the 166 valid questionnaires were considered for the data analysis giving use response rate of $92 \%$. Correlational and regression analysis was used to check the influence of the independent variables on the dependent variable while package of Preacher and Hayes 2016 was used for the mediation analysis. Limitations and Future Directions have been discussed in the study as well.
\end{abstract}

Keywords: brand reputation, brand identification, brand equity, brand affect, brand loyalty, apparel industry

\section{Introduction}

Marketing trends globally changes and contribute towards marketing, consumers know different prevailing trends and have become demanding their desire wants and demands. In global market, consumer expectation with their brand towards their demands, in this consumers' expectation towards brand loyalty increases. Loyalty of customer plays a important part that controls competitive advantage of businesses (Gremler \& Brown, 1996). A crucial issue that arises in continued success of an organization to meet its capability and maintain their customers and make consumers loyal to their brands (Dekimpe, Steenkamp, Mellens, \& Vanden Abeele, 1997, p. 405). Consumers loyal to organization build businesses by buying more products, paying superior pricing and providing new customers through supportive words of mouth about their brand (Ganesh, Arnold, \& Reynolds, 2000, p. 65). Brand loyalty described as keeping particular product and service and repurchase it again and again, reliable customers pay money for the same brand and speak positive words about brand. Brand affect describes the relationship between customer's and brand and it can be a evaluation of customer towards brand (Matzler et al., 2006). Brand affect is positive or either negative it depends on customer's perception about brand. Scholars also state that strong organizational relationships are based on customer's identification with organizations or with brand that to assist them to self-definitional needs (Bhattacharya \& Sen, 2003). The customer already connects to brand when they find that their brand is unique or different or something more and charming than other brands (Ahearne at al., 2005). Brand equity means to add an extra value in the brand name that will be acknowledge through the customers and it also means or reflects that customers are more captivating towards brand products (Rios \& Riquelme, 2008) For a brand to be profitable and successful it is very important that the brand must have a good reputation (Herbig, 1997). Fomburn,(1996) expresses reputation "the overall estimation in which a company is held by its constituents". 


\section{Literature Review}

\subsection{Brand Loyalty}

Assael (1998) expresses brand loyalty as the usage of the same brand that consumers use to satisfy his or her desires, this inculcates with the re purchase behavior. Studies has found that brand loyalty has a direct link with the preferences associated with brand preferences, which means that while purchasing various products consumers will not considered buying other brands product (Baldinger \& Rubinson, 1996; Cavero \& Cebollada, 1997). According to Oliver, (1999) brand loyalty signifies the commitment, where the consumers will purchase the products from the same brand and will to shift to other brands, since they are being loyal towards a specific brand. Brand loyalty is a mixture of attitude factors as well as behavioral factors. Behavioral factors include the repurchases behaviors and the attitude factor includes the psychological commitment towards the brand. (Aaker, 1991; Assael, 1998; Oliver,1999; Prus \& Brandt, 1995; Farr \& Hollis, 1997). Many famous researchers argue that consumers buying the same brand again and again cannot be considered or termed as loyal customers, consumers repurchase the product due to convent factors (Tseng, Liao, \& Jan, 2004). The perception of brand loyalty is seventy-five years old (Copeland 1923). According to Aaker (1996) defines brand loyalty as "the degree of a consumer emotional attachment to a brand". In addition to it (Oliver's study,1999) defines brand loyalty as repurchasing or buying the same brand again and again.

\subsection{Brand Reputation}

For a brand to be profitable and successful it is very important that the brand must have a good reputation (Herbig, 1997).

Fomburn, (1996) expresses reputation "the overall estimation in which a company is held by its constituents". Many famous scholars agree that positive reputation leads towards a profitable brand leading towards competitive prosperity in the markets (Roper \& Fill, 2012). When the people satisfy with the features and benefits of the product and intrinsically becomes loyal about the product. A reputable brand is considered to be the backbone of the organization leading towards an increase in the profitability and market shares of the company. The brand reputation depend upon the product quality and its value addition services at the premium price. Brand reputation has been defined as the overall performance of the company which in built in its mission and vision statement (Fombrun, 1996). When the practitioner and academicians built a synergy as a result the company leads towards the prosperity and gain distinctive advantage in the specific field (Roper \& Fill, 2012).In this context, both practitioners and scholars agree on the aspect that a positive reputation facilitates a profitable brand and leads to competitive benefits (Herbig \& Milewicz, 1995; Roper \& Fill, 2012).

\section{H1 = Brand Reputation has an influence on Brand Loyalty.}

\subsection{Brand Identification}

Identification happens when a person sees his or herself connected or know others. Identification means to know each other's or brand identification that customer knows about their specific brand they know about the fabric of brand and the quality of their brand or they are psychologically connected with their brands. Social identity theory postulate three components to make identification; a cognitive component; a evaluation component and an emotional component (Tajfel,1978).Scholars also state that strong organizational relationships are based on customer's identification with organizations or with brand that to assist them to self- definitional needs (Bhattacharya \& Sen, 2003) The customer already connects to the brand when they found that their brand is unique or different or something more charming in brand (Ahearne at al., 2005).A charming brand identity boosts the customer's self-estimation(Marin \& de Maya, 2013). Lam et al., (2013) defined that the brand identification is based on social identical theory. Socially identical means that the identification is a perception of an individual with groups or societies. The customer with more powerful brand identification can grab more pre-organizing activities of brand, as like assisting the organization purpose, saving the reputation of brand, supporting the products of brand and also supporting the brand loyalty. Brand identification also means when customer saws his or her reflection as brand reflection (Brodie, 2017)

\section{H2= Brand Identification has an influence on Brand Loyalty.}

\subsection{Brand Equity}

Brand equity means to add an extra value in the brand name that will be acknowledged through the customers and it also means to reflects that customers who are more captivating towards brand products (Rios \& Riquelme, 2008). The brand value has risen and creates standout among the distinctive elements for encouraging administrative capabilities (kim et al, 2005).The and feelings of alit class that save the name of brand it also saves the image of brand ,the 
symbols and signs of brand or image of brand by aspiring marketing (Dolal, 2003). Brand equity can also be maintained in purchasers through brands signs their logos, the true picture of brand, identity of brand, the specific taglines of brand and data and statistics of brand. Through this brand made his future brighter by excessing in dividends and makes the organization more to raise their dividends.

\section{H3= Brand Equity has an influence on Brand Loyalty.}

\subsection{Brand Affect}

Brand affect is basically explaining the customer's feeling about brand, the image of brand and also the emotions of brand. Emotions are more express able or clearer (Cohen \& Areni, 1991) but feelings are not as much as emotions because feelings are less powerful (Agarwal \& Malhotra, 2005). Brand affect is basically a customer's perception that is sometimes favorable and sometimes non-favorable.

Brand affect explains the connection between the customer's and brand and it can be a evaluation of customer towards brand (Matzler et al., 2006). Brand affect is positive or either negative it depends on customer's perception about brand. It is positing that if brand loyalty chances are means to be high than there are also circumstances of brand effectiveness to be on high level (Dick \& Basu, 1994).

$\mathrm{H} 4=$ Brand Affect has an influence on Brand Loyalty.

H5= Brand affect mediates the relationship between Brand Reputation and Brand Loyalty.

H6= Brand Affect mediates the relationship between Brand Identification and Brand Loyalty.

$\mathrm{H} 7=$ Brand Affect mediates the relationship between Brand Equity and Brand Loyalty.

\section{Theoretical Framework}

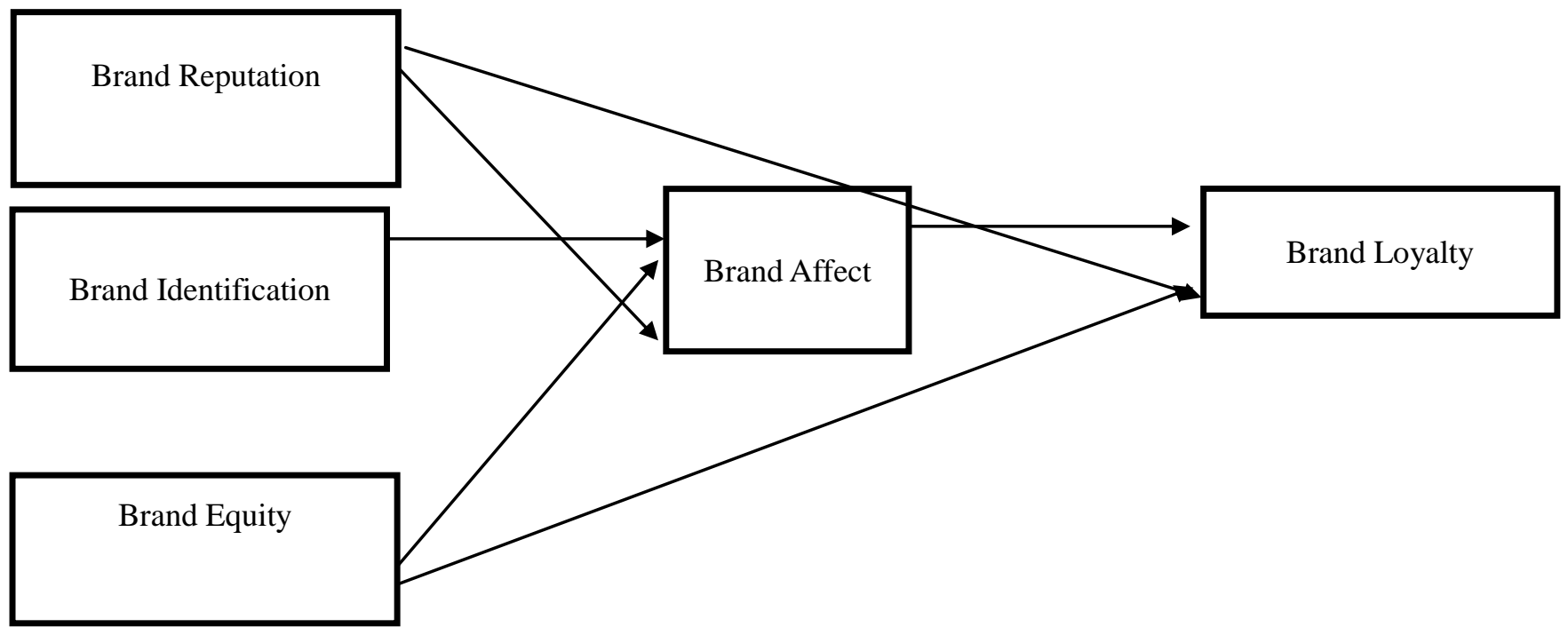

\section{Research Methodology}

This research is arranged to analyze impact of Brand Identification, Brand Understanding, Brand Reputation on Brand Loyalty: a mediating role of Brand Affect in Pakistan. The methodology adopted Survey as a research design and self-administered questionnaires were used for the collection of data. Non-probability convenience sampling technique was used. The sample size consisted of 180 respondents, where as we received 170 questionnaires. However, out of 170, 166 questionnaires were valid giving us a response rate of $92 \%$. For data evaluation purpose "Statistical Package for Social Sciences (SPSS 20.0)" is used in this research. We have taken the scales from the article of Han, Nguyen \& Smikin (2016). 


\section{Data Analysis}

Table 1. Demographics

\begin{tabular}{llll}
\hline Category & Classification & Frequency & Percentage (\%) \\
\hline Gender & Male & 80 & $48 \%$ \\
& Female & 86 & $52 \%$ \\
Age & $21-30$ & 158 & $95 \%$ \\
& $>30-40$ & 8 & $5 \%$ \\
Marital status & Married & 34 & $20 \%$ \\
& Single & 132 & $80 \%$ \\
\hline
\end{tabular}

Above table shows the Demographics of the data collected. Mostly the respondents were male $52 \%$ with having age from 31-30 and being single $80 \%$.

Table 2. Correlations

\begin{tabular}{llllll}
\hline Variables & BR & BI & BA & BE & BL \\
\hline Brand Reputation & 1 & & & & \\
Brand Identification & $.454^{* *}$ & 1 & & & \\
Brand Affect & -.001 & -.003 & 1 & & \\
Brand equity & .085 & $.257^{* *}$ & .172 & 1 & .042 \\
Brand Loyalty & $.562^{* *}$ & $.434^{* *}$ & $.242^{* *}$ & 1 \\
\hline
\end{tabular}

The above table shows that the relationship between brand reputation and brand loyalty is.562 ${ }^{* *}$ which shows that there is positive and moderate relationship between brand reputation and brand loyalty. Furthermore, the relationship is also highly significant. The relationship between brand identification and brand loyalty is $.434^{* *}$ which shows that there is again positive and moderate relationship between brand identification and brand loyalty and the relationship between them is highly significant. Similarly, the relationship between brand affect and brand loyalty is $.242^{* *}$ which shows that there is positive and weak relationship between brand affect and brand loyalty, and the relationship between them is highly significant. However, the relationship between brand equity and brand loyalty is .042 which shows that there is a positive but weak relationship and it is also not significant.

Table 3. Model Summary

\begin{tabular}{llllll}
\hline Model & R & R Square & Adjusted R Square & $\begin{array}{l}\text { Std. Error of } \\
\text { Estimate }\end{array}$ & ef \\
\hline 1 & .652 & .426 & .411 & .56234 \\
\hline
\end{tabular}

This table shows due to all the independent variables there is $.426 \%$ change in dependent variable.

Table 4. ANOVA

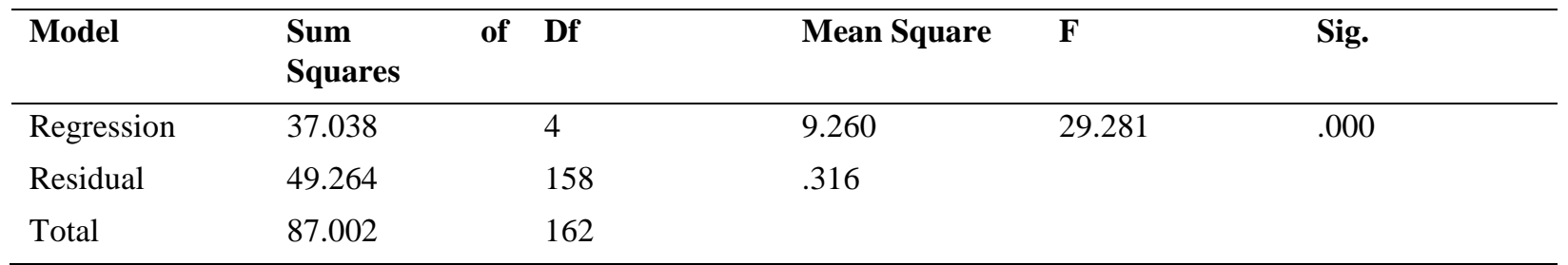

This table shows that fitness in model is 29.281 and the significance level is .000 which is highly significant. 
Table 5. Coefficients

\begin{tabular}{llllll}
\hline Variables & B & Std. Error & $\beta$ & T & Sig. Value \\
\hline $\begin{array}{l}\text { Brand } \\
\text { Reputation }\end{array}$ & .519 & .077 & .455 & 6.722 & .000 \\
$\begin{array}{l}\text { Brand } \\
\text { Identification }\end{array}$ & .246 & .067 & .256 & 3.663 & .000 \\
Brand Affect & .325 & .076 & .262 & 4.275 & .000 \\
Brand Equity & $\mathbf{- . 1 0 8}$ & .064 & -.107 & -1.693 & .092
\end{tabular}

Above table shows the coefficient of independent variable with dependent variable and what change will be in dependent variable due to independent variables. It shows that 1 unit of change in brand identification will bring about a change of .519 units in brand loyalty. This shows that impact is highly significant. Furthermore, change in brand identification will bring about a change of .246 units in brand loyalty, this also shows that the impact is significant. However, change in brand affect will bring about a change of .325 units in brand loyalty. Similarly, this also shows that the impact is significant. Moreover, change in brand equity will bring about a change of -.108. However, the impact is in significant.

Table 6. Mediation

\begin{tabular}{|c|c|c|c|}
\hline \multirow[t]{2}{*}{ BR---BA---BL } & $\begin{array}{l}\text { Direct Beta } \\
\text { Mediation }\end{array}$ & with Indirect Beta & Mediation Type \\
\hline & $.6410 * *$ & .0002 & No Mediation \\
\hline
\end{tabular}

Above table shows that there is no mediation between Brand Reputation and Brand Loyalty when considering Brand Affect as a mediator.

Table 7. Mediation

\begin{tabular}{|c|c|c|c|}
\hline BI---BA---BL & $\begin{array}{l}\text { Direct Beta } \\
\text { Mediation }\end{array}$ & with Indirect Beta & Mediation Type \\
\hline & $.4182 * *$ & .0008 & No Mediation \\
\hline
\end{tabular}

Above table shows that there is no mediation between Brand Identification and Brand Loyalty when considering Brand Affect as a mediator.

Table 8. Mediation

\begin{tabular}{|c|c|c|c|}
\hline BE---BA---BL & $\begin{array}{l}\text { Direct Beta } \\
\text { Mediation }\end{array}$ & with Indirect Beta & Mediation Type \\
\hline & .0006 & $.0418^{* *}$ & Full Mediation \\
\hline
\end{tabular}

Above table shows that there is full mediation between Brand Equity and Brand Loyalty when considering Brand Affect as a mediator.

\section{Discussion and Conclusion}

Current study has identified that brand reputation, brand identification and brand affect are positively related with brand loyalty. However, Brand equity was found to be having a insignificant relationship with brand loyalty. In relation to the aforementioned findings the reason behind it might be that brand reputation, brand identification and brand affect creates a sense of belongingness in user regarding his brand. These variables tend to associate a grand user to go for his brand again and again and therefore ultimately generating brand loyalty in customers. However, an interesting was that brand equity was not significantly related with brand loyalty and the reason behind might be that brand equity is mostly the concern of organization and therefore, customers tend to not having a significant sense towards brand loyalty in relation to brand equity.Brand reputation is the major concern of customers when they see brand loyalty and the study showed the same as it had the biggest variation in brand loyalty. Brand identification and brand affect were also impacting respectively in the dependent variable. The reason behind such findings might be that brand reputation enforces the value of the brand through social structure and thus re-enforcing the value of brand loyalty among customers. Same can be said about brand identification and brand affect as well. Interestingly, brand affect mediated the relationship of brand equity and brand loyalty and all other hypothesizes of mediation were rejected. These findings are in compliance with (Matzler et al., 2006), (Rios \& Riquelme, 2008), (kim et al, 2005). 


\section{Limitations and Future Directions}

- Quantitative analysis is used in this study however Qualitative analysis might enhance the understanding of the findings.

- $\quad$ Same Findings can be validated in other sectors as well.

- $\quad$ Time was of the essence therefore more data or longer style of research design might predict better results.

- $\quad$ SPSS 20.0 was used for quantitative analysis. More sophisticated software's (such as AMOS) or techniques can be used (Such as SEM).

- $\quad$ Higher level of sample size might produce better results.

\section{References}

Aaker, D.A. \& Keller, K.L. (1990). Consumer evaluations of brand extensions. Journal of Marketing, 54(1), 27-41. https://doi.org/10.1177/002224299005400102

Aaker, J.A. \& Maheswaren, D. (1997). The effect of cultural orientation on persuasion. Journal of Consumer Research, 24(3), 315-328. https://doi.org/10.1086/209513

Aaker, J. L., Benet-Martinez, V. \& Garolera, J. (2001). Consumption symbols as carriers of culture: A study of Japanese and Spanish brand personality constructs. Journal of personality and social psychology, 81(3), 492. https://doi.org/10.1037/0022-3514.81.3.492

Ahearne, M., Bhattacharya, C.B. \& Gruen, T. (2005). Antecedents and consequences of customer-company identification: expanding the role of relationship marketing. Journal of Applied Psychology, 90(3), 574-585. https://doi.org/10.1037/0021-9010.90.3.574

Banerjee, S. (2008), "Dimensions of Indian culture, core cultural values and marketing implications: An analysis", Cross Cultural Management: An International Journal, 15(4), $367-378$. https://doi.org/10.1108/13527600810914157

Banister, E.N. \& Hogg, M.K. (2004). Negative symbolic consumption and consumers' drive for self-esteem. European Journal of Marketing, 38(7), 850-868. https://doi.org/10.1108/03090560410539285

Bao, Y. \& Mandrik, C.A. (2004). Discerning store brand users from value consciousness consumers: the role of prestige sensitivity and need for cognition. Advances in Consumer Research, 31(1), 707-712.

Bartikowski, B. \& Walsh, G. (2011). Investigating mediators between corporate reputation and customer citizenship behaviors. Journal of Business Research, 64(1), 39-44. https://doi.org/10.1016/j.jbusres.2009.09.018

Chen, A., Peng, N. \& Hung, K. (2015). The effects of luxury restaurant environments on diners' emotions and loyalty: incorporating diner expectations into an extended Mehrabian-Russell model. International Journal of Contemporary Hospitality Management, 27(2), 236 - 260. https://doi.org/10.1108/IJCHM-07-2013-0280

Chou, C.M. (2013). Factors affecting brand identification and loyalty in online community. American Journal of Industrial and Business Management, 3(8), 674-680. https://doi.org/10.4236/ajibm.2013.38076

Cleveland, M., Papadopoulos, N. \& Laroche, M. (2011). Identity, demographics, and consumer behaviors: international market segmentation across product categories. International Marketing Review, $28(3), 244$ - 266. https://doi.org/10.1108/02651331111132848

Contractor, F.J. \& Kundu, S.K. (1998). Modal choice in a world of alliances: analyzing organizational forms in the international hotel sector. Journal of International Business Studies, 29(2), 325-357. https://doi.org/10.1057/palgrave.jibs.8490039

Craig, C.S. \& Douglas, S.P. (2006). Beyond national culture: implications of cultural dynamics for consumer research. International Marketing Review, 23(3), 322-342. https://doi.org/10.1108/02651330610670479

Crouch, G.I. \& Louviere, J.J. (2004). The determinants of convention site selection: A logistic choice model from experimental data. Journal of Travel Research, 43(2), 118-130. https://doi.org/10.1177/0047287504268233

Del Rio, A.B., Vazquez, R. \& Iglesias, V. (2001). The effects of brand associations on consumer response. Journal of Consumer Marketing, 18(5), 410-425. https://doi.org/10.1108/07363760110398808

De Mooij, M. (2010). Global Marketing and Advertising: Understanding Cultural Paradoxes (3rd ed), Sage, Singapore. 
Foxall, G. R., Goldsmith, R. E. \& Brown, S. (1998). Consumer psychology for marketing (Vol.1). International Thomson Business Press, London;Boston, MA.

Goldsmith, R. E., Flynn, L. R. \& Kim, D. (2010). Status consumption and price sensitivity., Journal of Marketing Theory and Practice, 18(4), 323-338. https://doi.org/10.2753/MTP1069-6679180402

Goldsmith, R.E., Flynn, L.R. \& Clark. R. A. (2012). Materialistic, brand engaged and status consuming consumers and clothing behaviors. Journal of Fashion Marketing and Management: An International Journal, 16(1), 102-119. https://doi.org/10.1108/13612021211203050

Graeff, T.R. (1996). Using promotional messages to manage the effects of brand and selfimage on brand evaluations. Journal of Consumer Marketing, 13(3), 4-18. https://doi.org/10.1108/07363769610118921

Granovetter, M. (1985). Economic action and social structure: the problem of embeddedness. The American Journal of Sociology, 91(3), 481-510. https://doi.org/10.1086/228311

Hair, J.F., Black, W.C., Babin, B.J., Anderson, R.E. \& Tatham, R.L. (2006). Multivariate Data Analysis. (6th ed.), Prentice Hall, New Jersey.

Hahm, S.P. \& Khan, M.A. (2014). Changing Food Consumption Patterns and Their Impact, in; Parsa, H.G. and Kwansa, F.A. (Eds), Quick Service Restaurants, Franchising, and Multi-Unit Chain Management, Routledge, New York and London.

Harris, L.C. \& Ezeh, C.E. (2008). Servicescapes and loyalty intentions: an empirical investigation. European Journal of Marketing, 42(3/4), 390-422. https://doi.org/10.1108/03090560810852995

Hennessey, H.D \& Jeannet, J.P. (2004). Global account management: Creating value. John Wiley \& Sons, Chichester.

Helm, S. (2011). Employees' awareness of their impact on corporate reputation. Journal of Business Research, 64(7), 657-663. https://doi.org/10.1016/j.jbusres.2010.09.001

Hofstede, G. (2001). Culture's Consequences (2nd ed.), Sage, CA.

Hong, J.W. \& Zinkhan, G.M. (1995). Self-concept and advertising effectiveness: the influence of congruency, conspicuousness, and response mode. Psychology \& Marketing, 12(1), 53-77. https://doi.org/10.1002/mar.4220120105

Horppu, M., Kuivalainen, O., Tarkiainen, A. \& Ellonen, H.K. (2008). Online satisfaction, trust and loyalty, and the impact of the offline parent brand. Journal of Product \& Brand Management, 17(6), 403-413. https://doi.org/10.1108/10610420810904149 